Article

\title{
An In Silico and In Vitro Study for Investigating Estrogenic Endocrine Effects of Emerging Persistent Pollutants Using Primary Hepatocytes from Grey Mullet (Mugil cephalus)
}

\author{
Paolo Cocci, Gilberto Mosconi and Francesco A. Palermo* \\ School of Biosciences and Veterinary Medicine, University of Camerino, Via Gentile III Da Varano, \\ I-62032 Camerino, MC, Italy; paolo.cocci@unicam.it (P.C.); gilberto.mosconi@unicam.it (G.M.) \\ * Correspondence: francesco.palermo@unicam.it
}

check for updates

Citation: Cocci, P.; Mosconi, G.; Palermo, F.A. An In Silico and In Vitro Study for Investigating

Estrogenic Endocrine Effects of Emerging Persistent Pollutants Using Primary Hepatocytes from Grey Mullet (Mugil cephalus). Environments 2021, 8, 58. https://doi.org/10.3390/ environments 8060058

Academic Editor: Sílvia C. Goncalves

Received: 14 May 2021

Accepted: 16 June 2021

Published: 18 June 2021

Publisher's Note: MDPI stays neutral with regard to jurisdictional claims in published maps and institutional affiliations.

Copyright: (C) 2021 by the authors. Licensee MDPI, Basel, Switzerland. This article is an open access article distributed under the terms and conditions of the Creative Commons Attribution (CC BY) license (https:/ / creativecommons.org/licenses/by/ $4.0 /)$.

\begin{abstract}
There is growing concern about the environmentally relevant concentrations of new emerging persistent organic pollutants, such as perfluorinated compounds and pharmaceuticals, which are found to bioaccumulate in aquatic organisms at concentrations suspected to cause reproductive toxicity due to the activation of estrogen receptor (ER) $\alpha$ and $\beta$ subtypes. Here, we use a combined in silico and in vitro approach to evaluate the impact of perfluorononanoic acid (PFNA) and Enalapril (ENA) on grey mullet (Mugil cephalus) hepatic estrogen signaling pathway. ENA had weak agonist activity on ER $\alpha$ while PFNA showed moderate to high agonist binding to both ERs. According to these effects, hepatocytes incubation for $48 \mathrm{~h}$ to PFNA resulted in a concentration-dependent upregulation of ER and vitellogenin gene expression profiles, whereas only a small increase was observed in ER $\alpha$ mRNA levels for the highest ENA concentration. These data suggest a structure-activity relationship between hepatic ERs and these emerging pollutants.
\end{abstract}

Keywords: endocrine disruptors; Mugil cephalus; PFNA

\section{Introduction}

Chemicals interfering with the endocrine system known as endocrine disrupting chemicals (EDCs) are pollutants that typically occur in aquatic environments as a result of municipal wastewater discharge, landfill leachates, and agricultural and urban runoff [1]. EDCs are considered a major cause of aquatic wildlife decline and loss of biodiversity [2]. Aquatic organisms such as fish may experience life-long exposures to EDCs and may bioaccumulate them developing a wide range of hormonal abnormalities [3]. Today, there is growing concern about the environmentally relevant concentrations of new emerging persistent pollutants, such as perfluorinated compounds (PFCs) and pharmaceuticals (e.g., contraceptives and anti-depressants), which are found to bioaccumulate in aquatic food webs at concentrations suspected to perturb neuro-endocrine processes in living organisms including humans $[4,5]$.

PFCs are synthetic chemical compounds that due to high stabilities and low surface tensions are increasingly used in various industrial applications and common consumer products [6]. Among PFCs, the perfluoroalkylated substances (PFAS) have been discovered as global pollutants remaining most persistently in each environmental compartment $[7,8]$. Although PFAS are considered moderately to highly toxic, some of these (e.g., perfluorooctane sulfonic acid (PFOS) and perfluorooctanoic acid (PFOA)) are suspected endocrine disruptors and have been found to cause adverse health effects, especially reproductive toxicity, in different vertebrate models $[9,10]$. Similarly, pharmaceuticals that include any chemical product used by individuals or agribusiness for promoting personal and livestock health, have aroused great interest as environmental pollutants for their ecotoxicological potentials [11,12]. These compounds have been detected, unchanged or as metabolites, in wastewater, surface and drinking waters throughout the world [13-15]. Calamari et al. [16] 
have defined pharmaceuticals as pseudo-persistent pollutants due to their continuous introduction into the environment, the biotic and/or abiotic transformation and the ability to exert subtle effects in non-target organisms. In this regard, the estrogenic potential of some pharmaceuticals has attracted great concern especially in the aquatic environment $[17,18]$.

Estrogen-like EDCs (xenoestrogens) have the capability to bind to the estrogen receptors (ERs), mimicking the female steroid hormone, $17 \beta$-estradiol (E2), and thus activating intracellular signaling pathways. Activation of the ER-mediated signaling pathway has been extensively studied in several models, particularly fish in which feminization has been considered a direct result of xenoestrogen contamination [19-23]. In this regard, the ER-induced hepatic vitellogenin (Vtg) production is typically used to confirm exposure to estrogenic compounds in male fish [24,25]. Of the different fish organ cells, liver cells are widely used in in vitro primary culture models due to their ability to retain native liver properties including estrogen responsiveness [26-28]. For that reason, in vitro methods using primary cultures of fish hepatocytes represent a fundamental and recommendable alternative to in vivo studies for investigating several toxicologically relevant mechanisms $[29,30]$.

In the present work, we focused our attention on the ability of perfluorononanoic acid (PFNA) and enalapril (ENA) to interfere with estrogen receptor signaling using a combined in silico/in vitro approach. The selected compounds belong to the most frequently detected classes of emerging EDCs in the aquatic environment such as PFAS and pharmaceuticals [31-35]. The Endocrine Disruptome program package was used to predict their potential interference with nuclear ERs in silico. A bioassay that uses primary hepatocytes from the grey mullet (Mugil cephalus) was then employed for screening estrogenic potential by assessing classical biomarker responses such as VTG protein and ER isoform mRNA expression. In addition, cytotoxicity using Alamar Blue and 3-(4,5dimethylthiazol-2-yl)-2,5-diphenyltetrazolium bromide (MTT) assays was evaluated after 24 and $48 \mathrm{~h}$ exposure.

\section{Materials and Methods}

\subsection{Endocrine Disruptome Screening Tool}

A molecular docking approach for predicting interactions between PFNA/ENA and estrogen receptor $\alpha(E R \alpha)$ and $\beta(E R \beta)$ ligand binding domains has been performed with Endocrine Disruptome Simulation (EDS) Tool. This web service has already been successfully adopted as a software tool for predicting the endocrine disruption potential of compounds, using well-validated crystal structures of 14 different human nuclear receptors including ER subtypes [36]. The crystal structures of 1A52, 3OLS, 1SJ0, and 1QKN have been chosen as templates on the basis of their sequence identity with fish receptors (higher than $60 \%$ ). The docking scores reported are a measure of how the contaminants fit within the receptor-binding pocket, taking into account continuum and discreet parameters. According to the threshold calculations sensitivity (SE), it is possible to obtain four broad groups indicating predicted affinity for ER isoforms as follows: "red" (SE $<0.25)$, high probability; "orange" $(0.25<\mathrm{SE}<0.50)$ and "yellow" $(0.50<\mathrm{SE}<0.75)$, medium probability; and "green" (SE > 0.75), low probability of binding [36].

\subsection{Hepatocyte Isolation and Primary Cell Culture}

Flathead grey mullet (Mugil cephalus) males ( $95.5 \pm 10.9 \mathrm{~g}$ initial weight) were provided by professional fishermen during fishing activities. Fish were acclimated for 2 weeks in $2.00 \mathrm{~m} \times 2.00 \mathrm{~m} \times 0.60 \mathrm{~m}$ tanks with constant aeration and natural photoperiod at Unità di Ricerca e Didattica of San Benedetto del Tronto (URDIS), University of Camerino in San Benedetto del Tronto (AP, Italy). Water quality parameters were monitored daily showing the following values: $\mathrm{pH} 8.4 \pm 0.2, \mathrm{O}_{2}=10.3 \pm 0.5 \mathrm{mg} \mathrm{L}^{-1}$, and temperature $=20-22{ }^{\circ} \mathrm{C}$, salinity $36 \pm 2 \mathrm{psu}$; undetectable level of nitrites and ammonia. Following the acclimation, fish were randomly euthanized using MS-222 within 5 min after capture. Animal manipulation was executed following the procedures established by the Italian law (Leg- 
islative Decree 116/1992), the European Communities Council Directive (86/609/EEC and 2010/63/EU) for animal welfare and under the supervision of the authorized investigators. The liver tissue was collected to obtain hepatocytes under a laminar flow hood, according to Cocci et al. [37] and Palermo et al. [38]. Purified hepatocytes were suspended in Leibovitz (L-15) phenol red-free medium, antibiotic-antimycotic solution $(100 \mathrm{U} / \mathrm{mL})$ and $10 \mathrm{mM}$ HEPES. The cell density was measured in a Burker Chamber and the viability of hepatocytes was over $90 \%$, as assessed with the Trypan blue exclusion assay. Cells were seeded on 24-well Falcon Primaria culture plates $\left(1 \times 10^{6}\right.$ cells per well $)$ in L-15 phenol red-free medium, antibiotic-antimycotic solution $(100 \mathrm{U} / \mathrm{mL})$ and $10 \mathrm{mM}$ HEPES. Cells were cultured for $24 \mathrm{~h}$ in an incubator at $23{ }^{\circ} \mathrm{C}$ before chemical exposure to allow attachment. Then, $50 \%$ of the L- 15 phenol red-free medium culture was removed, and hepatocytes were exposed to medium containing the vehicle (ethanol, final concentration $0.01 \%$ ) and 1.0, 0.01 , or $0.0001 \mu \mathrm{M}$ of E2, ENA or PFNA. Hepatocytes were incubated in an incubator at $23^{\circ} \mathrm{C}$ for $96 \mathrm{~h}$. Media and cells were harvested separately at $0,24,48,72$ and $96 \mathrm{~h}$ with medium changes every $24 \mathrm{~h}$. Doses of ENA and PFNA were chosen on the basis of environmentally relevant concentrations [33,39-41] and six independent wells were setup for both the control and each concentration of compound. The entire experiment was repeated 3 times.

\subsection{MTT Cytotoxicity Assay}

The 3-(4,5-dimethylthiazol-2-yl)-2,5-diphenyl-tetrazoliumbromide (MTT) activity was measured according to Smeets et al. [42] with slight modifications, using the MTT Cell Proliferation and Cytotoxicity Assay Kit assay (Boster Biological Technology, Pleasanton, CA, USA, Catalog \# AR1156). After 0, 24, 48, 72, 96 h of treatment described above, incubation medium was removed and replaced with fresh culture medium containing MTT reagent $(5 \mathrm{mg} / \mathrm{mL}$ MTT diluted in phosphate buffered saline, PBS). After an incubation of $40 \mathrm{~min}$ at $23{ }^{\circ} \mathrm{C}$, the formazan crystals produced were solubilized by adding $200 \mu \mathrm{L}$ Formazan solubilization solution. After the complete solubilization, $200 \mu \mathrm{L}$ of medium was transferred to a 96-well microplate and absorbance values were measured at $570 \mathrm{~nm}$ using a microplate reader (BioChrom, Cambridge, UK).

\subsection{Alamar Blue Assay}

Cell viability was also quantified using the Alamar Blue ${ }^{\mathrm{TM}}$ assay reagent (Thermo Scientific, Waltham, MA, USA) as described by Cocci et al. [23] and following manufacturer's specifications. The incubation medium was removed after $24,48,72,96 \mathrm{~h}$ of treatment, replaced with a fresh culture medium containing $\mathrm{AB}$ reagent at a final concentration of $10 \%$, and incubated for an additional $1 \mathrm{~h}$. The absorbance was monitored at 570/600 nm using a microplate reader. The cell viability was normalized to that of hepatocytes cultured in the regular media without any of the tested compounds.

\subsection{Quantitative Realtime PCR ( $q-P C R)$}

After exposure, the medium was carefully removed, and cells were lysed by adding the TRIzol reagent (Invitrogen Life Technologies, Milan, Italy). Total RNA was isolated according to the manufacturer's specifications. RNA quality and concentration were measured spectrophotometrically at $260 / 280 \mathrm{~nm}$, and purity was confirmed by electrophoresis through $1 \%$ agarose gels stained with SafeView Classic (abm). The cDNA was synthesized from $1.5 \mu \mathrm{g}$ of total RNA in $20 \mu \mathrm{L}$ using the 5X All-In-One RT MasterMix (with AccuRT Genomic DNA Removal Kit) according to manufacturer's instructions (abm). SYBR greenbased real-time PCR was used to evaluate expression profiles of ER $\alpha$, ER $\beta$, VTG target genes. 18 s rRNA was selected as appropriate reference gene $[28,43,44]$. All the primer sequences are reported in Table 1 and were provided from Ribecco et al. [45], Vieira et al. [46], Cabas et al. [47], and Perez-Sanchez et al. [48]. The reaction included $10 \mu \mathrm{L}$ of $2 X$ BlasTaq $^{\mathrm{TM}}$ qPCR MasterMix (abm), $0.5 \mu \mathrm{L}$ each of forward and reverse primers $(10 \mu \mathrm{M}), 2 \mu \mathrm{L}$ of cDNA template, and nuclease-free $\mathrm{H}_{2} \mathrm{O}$ to a final volume of $20 \mu \mathrm{L}$. The expression of individual 
gene targets was analyzed using the ABI 7300 Real-Time PCR software. Thermo-cycling for all reactions was for $3 \mathrm{~min}$ at $95^{\circ} \mathrm{C}$, followed by 40 cycle of $15 \mathrm{~s}$ at $95^{\circ} \mathrm{C}$, and $60 \mathrm{~s}$ at $60{ }^{\circ} \mathrm{C}$. Dissociation curve analysis revealed that a single peak was generated during the reaction demonstrating the production of a single product. Each amplified fragment was then compared with that obtained from amplification of Sparus aurata cDNA and verified with agarose gel electrophoresis (for details see Figure S1 in Supplementary Material). The efficiency of qPCR primer sets was reported in Table 1. Results were calculated using the $2^{-\Delta \Delta C t}$ method and reported as fold change corrected for $18 \mathrm{~s}$ rRNA and with respect to vehicle levels. Values are the mean \pm SD of three independent experiments.

Table 1. List of primers used in this study.

\begin{tabular}{|c|c|c|c|c|}
\hline Gene & Primer Sequence $\left(5^{\prime}-3^{\prime}\right)$ & Genbank & Product Size & Efficiency $(\%)$ \\
\hline $\mathrm{ER} \alpha$ & $\begin{array}{l}\text { CTGGTGCCTTCTCTTTTTGC } \\
\text { TGTCTGATGTGGGAGAGCAG }\end{array}$ & AF136979 & 181 & 96.85 \\
\hline $\mathrm{ER} \beta$ & $\begin{array}{l}\text { TGTCATCGGGCGGGAAGG } \\
\text { GCTCTTACGGCGGTTCTTGTCT }\end{array}$ & AF136980 & 188 & 91.74 \\
\hline VTG & $\begin{array}{l}\text { CTGCTGAAGAGGGACCAGAC } \\
\text { TTGCCTGCAGGATGATGATA }\end{array}$ & AF210428 & 158 & 96.31 \\
\hline 18s rRNA & $\begin{array}{l}\text { GCATTTATCAGACCCAAAACC } \\
\text { AGTTGATAGGGCAGACATTCG }\end{array}$ & AY993930 & 135 & 98.65 \\
\hline
\end{tabular}

\subsection{Enzyme-Linked Immunosorbent Assay (ELISA)}

VTG concentrations in the culture medium of Mugil cephalus hepatocytes were determined using an ELISA method previously published [25]. Cell culture media were diluted 1:8 as reported for routinely diluted media samples by Navas and Segner [49]. All samples were analyzed in triplicate. Absorbance was recorded at $492 \mathrm{~nm}$ using a microplate reader (Biochrom).

\subsection{Statistical Analysis}

Data were assessed with Graphpad prism v6.01 software (GraphPad Software Inc., San Diego, CA, USA) and expressed as mean \pm standard error of the mean (SEM). Statistical analysis was performed using ANOVA (one-way analysis of variance) followed by Bonferroni's multiple comparison test. Differences with $p<0.05$ were considered statistically significant.

\section{Results and Discussion}

The prediction results obtained with the EDS model for ENA and PFNA are given in Table 2.

ENA is a drug of the class of angiotensin-converting enzyme inhibitors (ACEI) that is mainly used in the treatment of arterial hypertension. Several studies indicate a beneficial interaction between ACEI and estrogens which in turn are involved in reducing ACE mRNA concentrations [50]. Zilberman et al. [51] showed that chronic exposure to ENA significantly up-regulated ER $\alpha$ and $\beta$ protein expression in rats. To date, however, there is no experimental evidence that ACEI can bind directly to ERs. Thus, it is not surprising that, according to EDS simulation, ENA presents moderate binding affinity against the agonist-active conformation of the $\mathrm{ER} \alpha$ and low affinity for both conformations of the $\operatorname{ER} \beta$, respectively.

PFNA is one of the three main long chain PFCs, primarily used as an emulsifier for producing fluoropolymers, that can be found at high concentrations in the environment [52]. PFNA has been detected in various waters and animal tissues worldwide suggesting high bioaccumulation potential in the food chain [53,54]. In mammalian studies, an interference with gonadal development in neonatal mice was observed after gestational exposure to PFNA [55]. In addition, an increase in estrogenic activity was reported for exposure to different PFCs, including PFNA, in in vivo studies using fish as models [56,57]. The 
results of in silico analysis obtained for PFNA allow us to support these effects because the simulation tool predicts its agonist activity on the ERs, showing a high probability of binding on ER $\beta$ and a slightly below probability on ER $\alpha$. Only the agonist activity on the $\mathrm{ER} \alpha$ from different species was previously described in the literature [56]. This latter paper reported that PFNA docked into the LBD region of ER $\alpha$ working as in vitro weak binders and activators. In the present study, PFNA docking scores for ER $\beta$ were more favorable than those for the ER $\alpha$. In addition, an antagonist activity on the ER $\beta$ was also predicted but any evidence of this potential activity has been found in the literature.

Table 2. Prediction affinities for $17 \beta$-Estradiol (E2), Enalapril (ENA) and perfluorononanoic acid (PFNA). +/ - indicate the crystal structures of estrogen receptors (ER) isoforms in complex with their respective agonist (+) or antagonist ligands (-).

\begin{tabular}{|c|c|c|c|}
\hline CAS & Name & Structure & $\begin{array}{c}\text { Receptor/Predictions Free Binding } \\
\text { Energies (kcal mol }{ }^{-1} \text { ) }\end{array}$ \\
\hline $50-28-2$ & E2 & & $\begin{array}{c}\mathrm{ER} \alpha+(-10.2) \\
\mathrm{ER} \alpha-(-10.0) \\
\mathrm{ER} \beta+(-9.6) \\
\mathrm{ER} \beta-(-8.8)\end{array}$ \\
\hline 75847-73-3 & ENA & & $\begin{array}{l}\mathrm{ER} \alpha+(-8.3) \\
\mathrm{ER} \alpha-(-7.7) \\
\mathrm{ER} \beta+(-6.8) \\
\mathrm{ER} \beta-(-7.8)\end{array}$ \\
\hline $375-95-1$ & PFNA & & $\begin{array}{c}\mathrm{ER} \alpha+(-8.9) \\
\mathrm{ER} \alpha-(-9.1) \\
\mathrm{ER} \beta+(-9.7) \\
\mathrm{ER} \beta-(-8.9)\end{array}$ \\
\hline
\end{tabular}

In order to determine whether a structure-activity relationship between ERs and tested compounds was evident, primary cultures of grey mullet hepatocytes were used to investigate the impact of PFNA and ENA exposure on ER $\alpha / \beta$ and VTG expression. In the first stage of our study, we examined whether the tested chemical compounds affected cellular viability by using common in vitro cytotoxicity assays such as Alamar Blue and MTT. The cell viability was expressed as metabolic activity, displaying $100 \%$ viability in the media of both negative (EtOH) and positive control (E2) at each time point (Figure 1A).

In contrast, a significant inhibition of metabolic activity was obtained for both ENA and PFNA. We found that cell viability decreased in hepatocytes after exposure to the highest doses of ENA for $72 \mathrm{~h}(84.8 \%$ and $81.1 \%$ of solvent control at 0.01 and $1 \mu \mathrm{M}$ ENA, respectively) and $96 \mathrm{~h}(89.3 \%$ and $65.0 \%$ at 0.01 and $1 \mu \mathrm{M}$ ENA, respectively) (Figure 1B). Similarly, exposure of hepatocytes to $0.01-1 \mu \mathrm{M}$ PFNA induced a significant change in viability at both $72 \mathrm{~h}$ (cell viability $86.7 \%$ and $67.5 \%$, respectively) and $96 \mathrm{~h}$ (cell viability $71.7 \%$ and $53.9 \%$, respectively) after the start of treatment (Figure $1 \mathrm{C}$ ). Complete cell death was confirmed by microscopic examination of cells exposed to the tested chemicals. The observed effects on cell viability were further investigated using the MTT assay (Figure 2). ENA and PFNA performed similarly in both assays, showing the most significant decrease in hepatocyte viability (from $71.7 \%$ to $53.9 \%$ ) exposed to the highest concentrations $(0.01$ and $1 \mu \mathrm{M}$ ) for $96 \mathrm{~h}$ (Figure 2B,C). However, the MTT assay failed to detect cytotoxicity for PFNA at $0.01 \mu \mathrm{M}$ after $72 \mathrm{~h}$ exposure, thus proving to be slightly less sensitive than the Alamar Blue assay.

To our knowledge, only one study has shown that ENA elicits specific cytotoxic effects in primary cultures of hepatocytes through the involvement of a glutathione-dependent detoxification pathway [58]. This effect was observed at concentrations ranging from 0.5 to $2 \mathrm{mM}$ in an in vitro rat cell model. The potential cytotoxic and antiproliferative effects of ENA were also found at concentration- and time-dependent manners in human HL60 acute promyelocytic leukaemia cells [59]. Interestingly, viability of ENA-treated HL60 cells was observed to drop by about $20 \%$ after exposure to $3 \mu \mathrm{M}$ for $48 \mathrm{~h}$. On the other hand, the 
effect of PFNA on hepatocyte viability was previously demonstrated in humans, using the WST-1 assay.

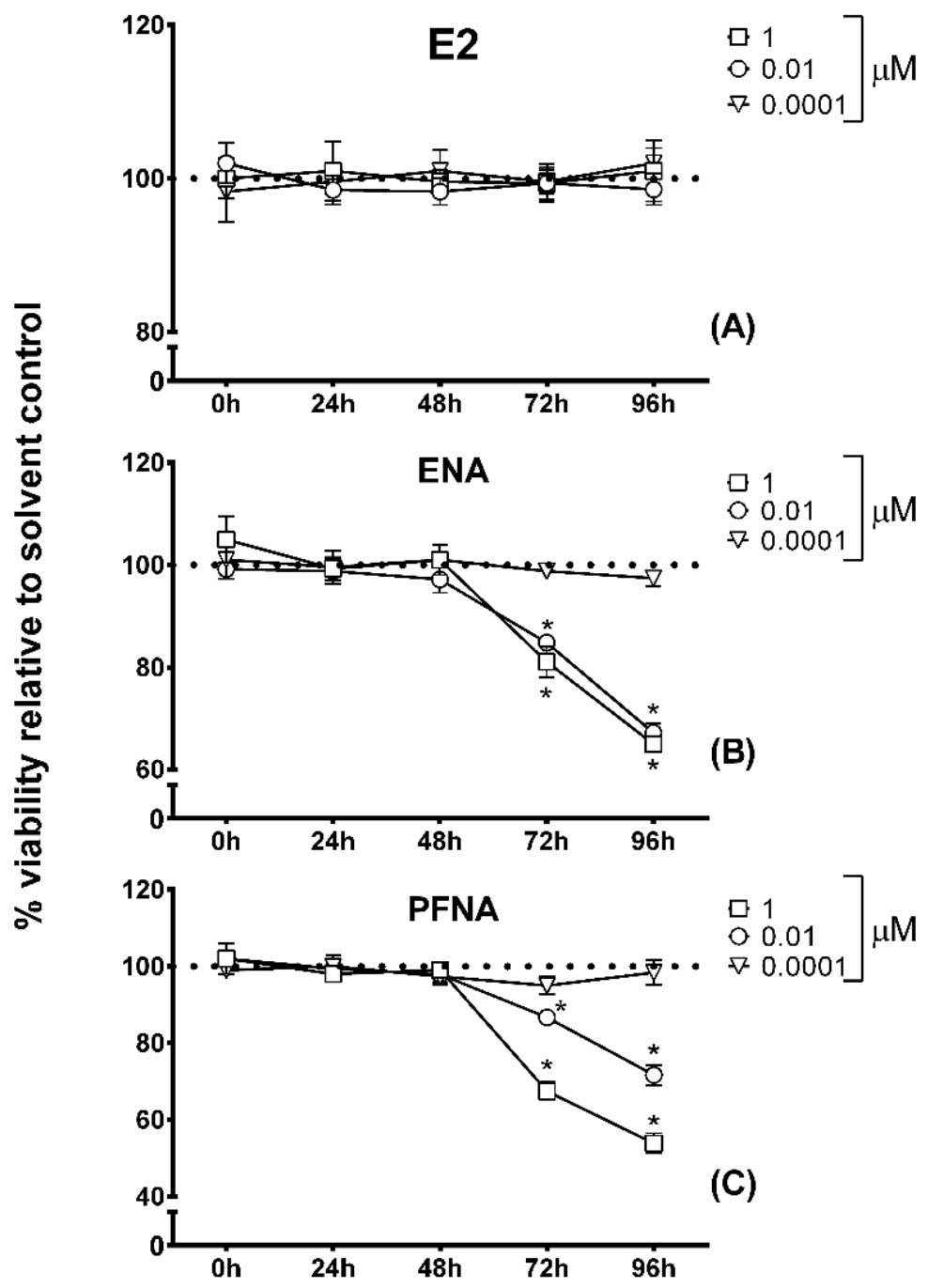

Figure 1. Alamar Blue cell viability of Mugil cephalus hepatocytes following exposure to E2 (A), ENA (B), PFNA (C) for up to $96 \mathrm{~h}$. The dot line represents cell viability measured in the solvent control (assigned a survival of $100 \%$ ). Values are given as mean \pm SEM of three independent experiments and expressed as \% relative to the solvent control. "** indicates significant differences between control and treated groups $(p<0.05)$.

PFNA was found to be more cytotoxic than PFOA and PFOS, causing a larger decrease in cell viability upon exposure for 6-72 $\mathrm{h}$ to a concentration range of 200- $400 \mu \mathrm{M}$ [60]. According to the obtained results, treatment incubation for 24 or $48 \mathrm{~h}$ was applied in the further studies. However, the exposure duration and sampling time of $24 \mathrm{~h}$ for all molecular endpoints were found to be inappropriate to obtain a clear concentration response of the model compounds (Figure 3A-C). As expected, $48 \mathrm{~h}$ exposure to positive control (E2) produced a dose-dependent induced expression of ERs and VTG compared with control hepatocytes (Figure 3D). In contrast, a partial concentration-response curve $(0.01-1 \mu \mathrm{M})$ for expression of all molecular endpoints was obtained for the model compound PFNA after $48 \mathrm{~h}$ of exposure (Figure $3 \mathrm{E}$ ), whereas only a small increase was observed in ER $\alpha$ mRNA levels for $1 \mu \mathrm{M}$ ENA (Figure 3F). 


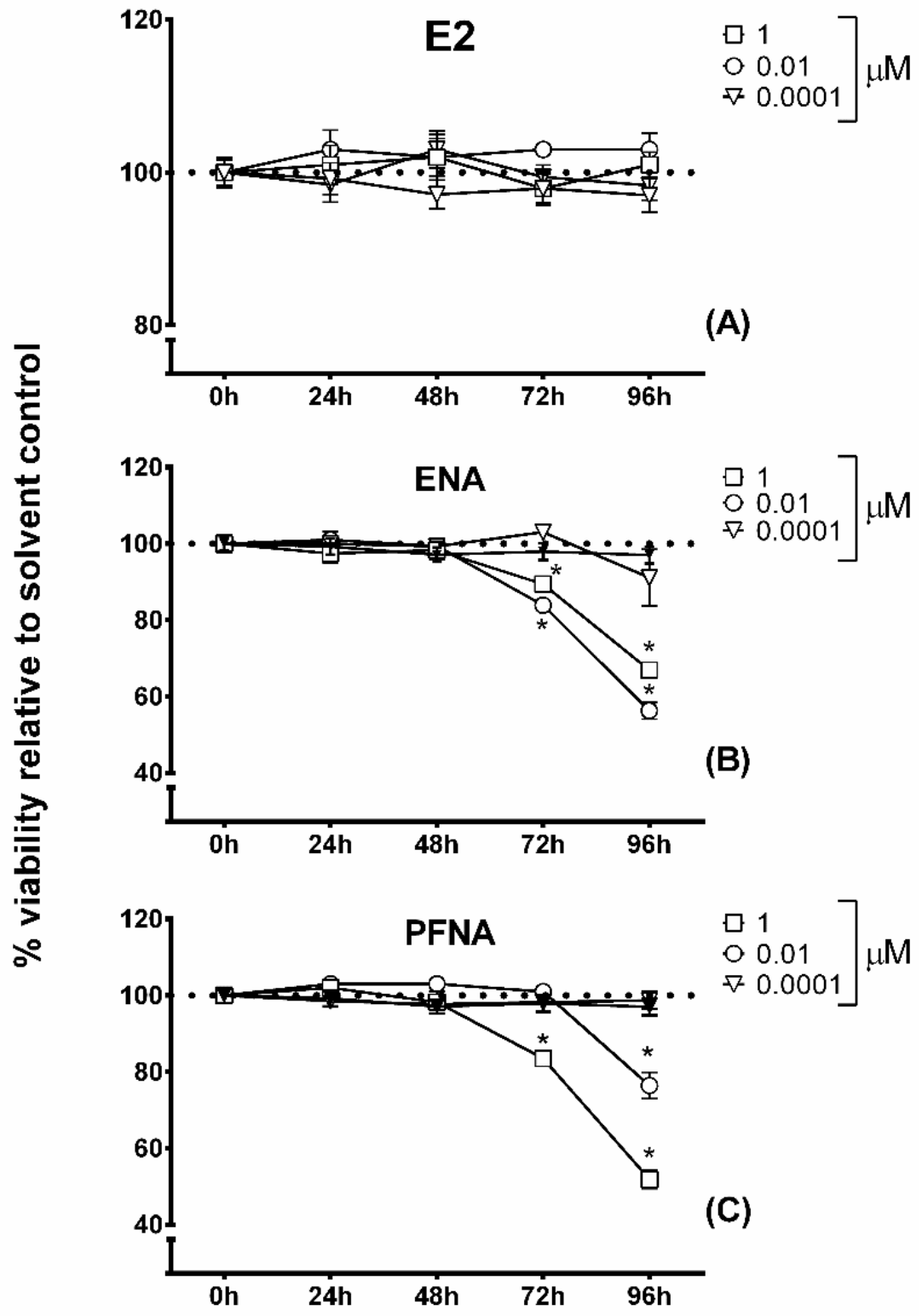

Figure 2. MTT assay of Mugil cephalus hepatocytes following exposure to E2 (A), ENA (B), PFNA (C) for up to $96 \mathrm{~h}$. The dot line represents cell viability measured in the solvent control (assigned a survival of $100 \%$ ). Values are given as mean \pm SEM of three independent experiments in $\%$ relative to the solvent control. "** indicates significant differences between control and treated groups $(p<0.05)$.

We further discuss the mRNA expression of VTG at the level of protein concentrations in the medium used for the primary cultures of grey mullet hepatocytes. At $48 \mathrm{~h}$ after treatment, E2 caused a significant dose-dependent increase in VTG synthesis at any of the tested concentrations relative to control cultures (Figure 4). Both PFNA and ENA also increased the VTG synthesis, but to a lesser extent. Indeed, a significant increase in VTG levels occurred following treatment with the highest doses $(0.01$ and $1 \mu \mathrm{M})$ of PFNA. In contrast, VTG up-regulation was only induced in response to exposure at $1 \mu \mathrm{M}$ ENA. 

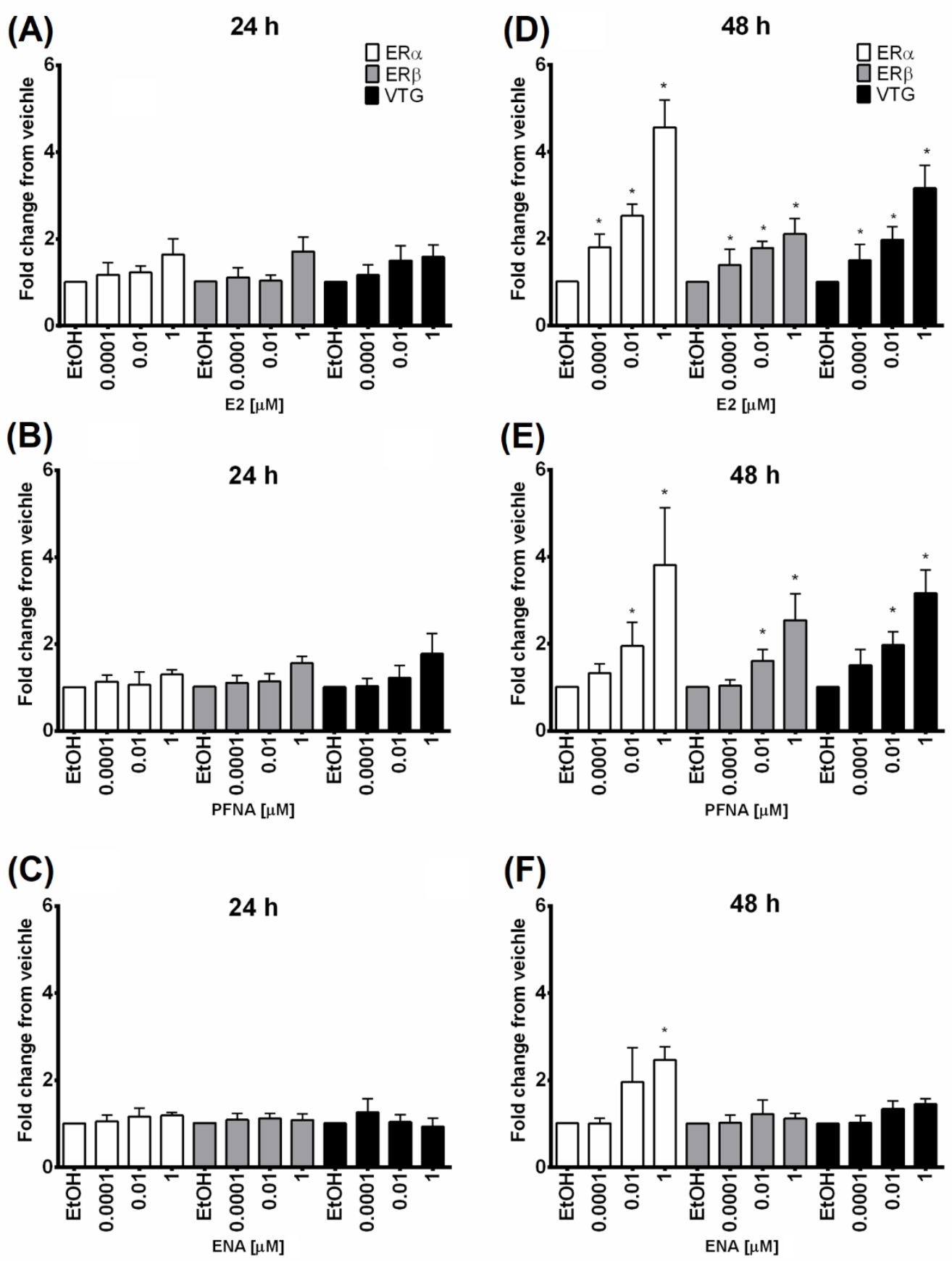

Figure 3. ER $\alpha, E R \beta$ and VTG mRNA expression profile (fold change from vehicle) in Mugil cephalus hepatocytes exposed to different concentrations (0.0001-1 $\mu \mathrm{M})$ of E2 (A,D), PFNA (B,E), ENA (C,F) for 24 and $48 \mathrm{~h}$. Values are mean \pm SEM of three independent experiments. " $* *$ indicates significant differences between control and treated groups $(p<0.05)$.

ER-mediated production of VTG is likewise by far the most used biomarker of xenoestrogen exposure in oviparous species [61-65]. VTG protein and gene expression has been shown to be up-regulated by various environmental pollutants in a number of in vitro-in vivo studies using fish models [66-68]. Interestingly, most of these works have found that VTG induction is accompanied by a clear increase in hepatic ER expression, mainly ER $\alpha$. This latter is indeed considered the ER subtype with a major role in mediating VTG gene induction. However, there is evidence that ER $\beta$ subtype may have a functional role in the up-regulation of ER $\alpha$ enhancing hepatic VTG induction in response to E2 or xenoestrogen stimulation $[69,70]$. Our results on PFNA are in agreement with those of Benninghoff et al. [56] who, in a recent study, found both in vitro and in vivo 
weak estrogenic activities of this PFC using a similar range of concentrations. Indeed, according to the relative binding affinity (RBA) values obtained in vitro, dietary PFNA also induced a consistent in vivo VTG induction in trout [56]. Collectively, our findings provide clear confirmation of data reported so far regarding the ability of PFNA to act as weak environmental xenoestrogen. PFNA has frequently been detected in surface waters at concentrations in the order of ng/L showing particularly high levels (up to a max of $100 \mathrm{ng} / \mathrm{L}$ ) in the recycling sites due to the recycling activities of electrical and electronic waste [40,71]. Thus, the prominence of PFNA in water from this typology of sites suggests the need of a careful monitoring of this potential xenoestrogen in order to reduce its ecological impact in aquatic ecosystems.

\section{VTG}

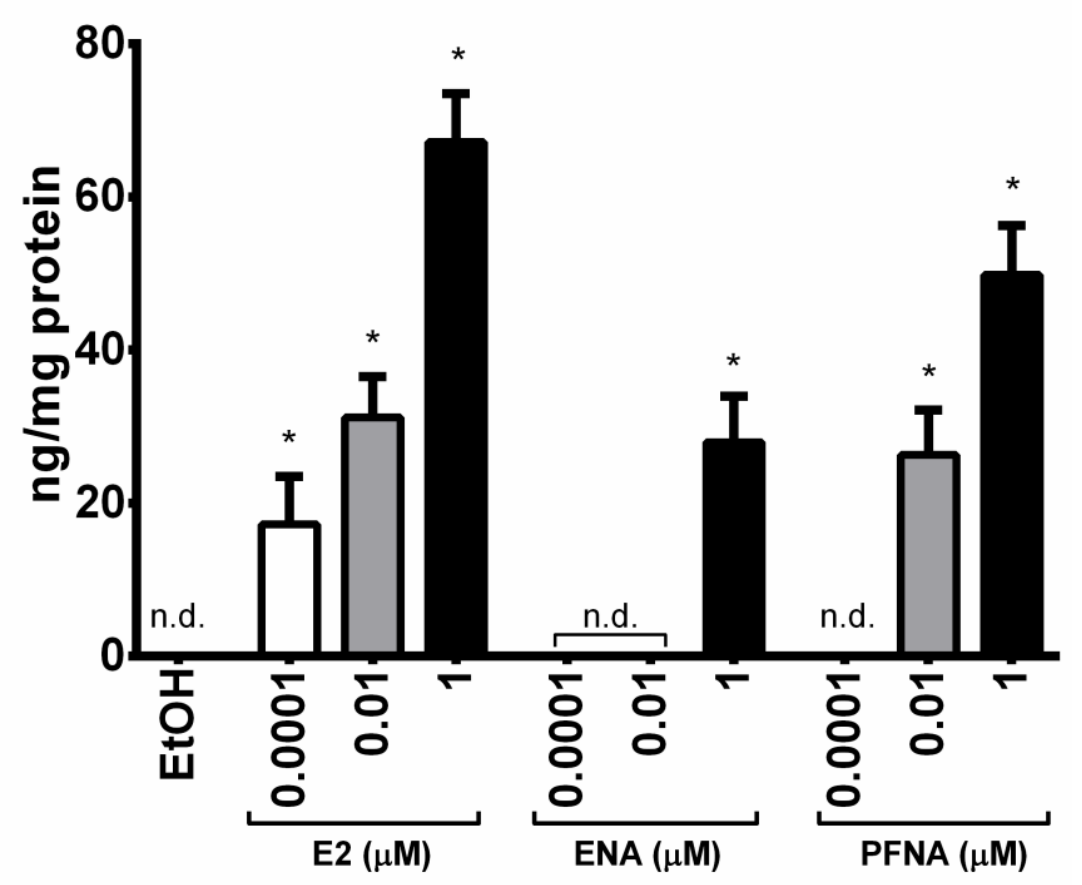

Figure 4. Changes in medium VTG levels in Mugil cephalus hepatocytes exposed to different concentrations (0.0001-1 $\mu \mathrm{M})$ of E2, ENA, PFNA for 48 h. n.d.: not detectable. "**" indicates significant differences between control and treated groups $(p<0.05)$.

Similarly, the occurrence of ENA in the environment can be related to incomplete removal of this drug from wastewater treatment plants (WWTPs). ENA was detected in wastewater influent at concentrations ranging from 35 to $1400 \mathrm{ng} / \mathrm{L}$, while in the wastewater effluent this range was reduced to $0.85-290 \mathrm{ng} / \mathrm{L}$ [39]. These data demonstrate that total or high removal of this drug can be achieved in all WWTPs, thus suggesting a substantially lower accumulation rate. Given also our results about the weak estrogenic potential, one might predict that ENA has a mild impact on reproductive functions of aquatic vertebrates.

\section{Conclusions}

In summary, an in vitro hepatocyte bioassay was used to characterize estrogenic responses of gray mullet to PFNA and ENA as representative compounds of two classes of emerging pollutants. According to the environmental occurrence of these chemicals, the results would indicate potential adverse impacts especially on reproductive health. The observed effects are likely to be mediated through direct actions of these compounds on hepatic ERs suggesting a structure-activity relationship between ER and these emerging pollutants. While the extent of PFNA estrogenic potential is substantially supported 
by literature data, further studies such as in vivo investigations need to obtain more information on the estrogenic activity of ENA, especially to check its effectiveness following long-term accumulation.

Supplementary Materials: The following are available online at https:/ / www.mdpi.com/article/10 .3390 / environments8060058/s1, Figure S1. Results of PCR amplification using template DNA from Mugil cephalus or Sparus aurata.

Author Contributions: Conceptualization, P.C. and F.A.P.; methodology, P.C., G.M., F.A.P.; formal analysis, F.A.P.; investigation, P.C., G.M.; resources, F.A.P.; writing—original draft preparation, P.C., F.A.P.; writing-review and editing, F.A.P.; supervision, F.A.P. All authors have read and agreed to the published version of the manuscript.

Funding: This research received no external funding.

Informed Consent Statement: Not applicable.

Data Availability Statement: The data presented in this study are available in the article/supplementary material, further inquiries can be directed to the corresponding author.

Conflicts of Interest: The authors declare no conflict of interest.

\section{References}

1. Ng, A.; Weerakoon, D.; Lim, E.; Padhye, L.P. Fate of environmental pollutants. Water Environ. Res. 2019, 91, 1294-1325. [CrossRef] [PubMed]

2. Zhou, J.; Cai, Z.-H.; Zhu, X.-S. Are endocrine disruptors among the causes of the deterioration of aquatic biodiversity? Integr. Environ. Assess. Manag. 2010, 6, 492-498. [CrossRef] [PubMed]

3. Celino-Brady, F.T.; Lerner, D.T.; Seale, A.P. Experimental Approaches for Characterizing the Endocrine-Disrupting Effects of Environmental Chemicals in Fish. Front. Endocrinol. 2021, 11, 619361. [CrossRef] [PubMed]

4. Corsini, E.; Luebke, R.W.; Germolec, D.R.; DeWitt, J.C. Perfluorinated compounds: Emerging POPs with potential immunotoxicity. Toxicol. Lett. 2014, 230, 263-270. [CrossRef]

5. Wilkinson, J.L.; Hooda, P.S.; Barker, J.; Barton, S.; Swinden, J. Ecotoxic pharmaceuticals, personal care products, and other emerging contaminants: A review of environmental, receptor-mediated, developmental, and epigenetic toxicity with discussion of proposed toxicity to humans. Crit. Rev. Environ. Sci. Technol. 2015, 46, 336-381. [CrossRef]

6. OECD. Summary Report on the New Comprehensive Global Database of Per-and Polyfluoroalkyl Substances (PFASs); Publications Series on Risk Management: Paris, France, 2018; No. 39.

7. Houde, M.; Martin, J.W.; Letcher, R.J.; Solomon, K.R.; Muir, D.C.G. Biological Monitoring of Polyfluoroalkyl Substances: A Review. Environ. Sci. Technol. 2006, 40,3463-3473. [CrossRef]

8. Valsecchi, S.; Rusconi, M.; Polesello, S. Determination of perfluorinated compounds in aquatic organisms: A review. Anal. Bioanal. Chem. 2012, 405, 143-157. [CrossRef]

9. White, S.S.; Fenton, S.E.; Hines, E.P. Endocrine disrupting properties of perfluorooctanoic acid. J. Steroid Biochem. Mol. Biol. 2011, 127, 16-26. [CrossRef]

10. Zeng, Z.; Song, B.; Xiao, R.; Zeng, G.; Gong, J.; Chen, M.; Xu, P.; Zhang, P.; Shen, M.; Yi, H. Assessing the human health risks of perfluorooctane sulfonate by in vivo and in vitro studies. Environ. Int. 2019, 126, 598-610. [CrossRef]

11. Fent, K.; Weston, A.A.; Caminada, D. Ecotoxicology of human pharmaceuticals. Aquat. Toxicol. 2006, 76, 122-159. [CrossRef]

12. Liu, N.; Jin, X.; Feng, C.; Wang, Z.; Wu, F.; Johnson, A.C.; Xiao, H.; Hollert, H.; Giesy, J.P. Ecological risk assessment of fifty pharmaceuticals and personal care products (PPCPs) in Chinese surface waters: A proposed multiple-level system. Environ. Int. 2020, 136, 105454. [CrossRef] [PubMed]

13. Pereira, A.; Silva, L.; Laranjeiro, C.; Lino, C.; Pena, A. Selected Pharmaceuticals in Different Aquatic Compartments: Part I-Source, Fate and Occurrence. Molecules 2020, 25, 1026. [CrossRef]

14. Patel, M.; Kumar, R.; Kishor, K.; Mlsna, T.; Pittman, C.U., Jr.; Mohan, D. Pharmaceuticals of Emerging Concern in Aquatic Systems: Chemistry, Occurrence, Effects, and Removal Methods. Chem. Rev. 2019, 119, 3510-3673. [CrossRef]

15. Zuccato, E.; Castiglioni, S.; Fanelli, R.; Reitano, G.; Bagnati, R.; Chiabrando, C.; Pomati, F.; Rossetti, C.; Calamari, D. Pharmaceuticals in the Environment in Italy: Causes, Occurrence, Effects and Control. Environ. Sci. Pollut. Res. 2006, 13, 15-21. [CrossRef]

16. Calamari, D.; Zuccato, E.; Castiglioni, S.; Bagnati, R.; Fanelli, R. Strategic Survey of Therapeutic Drugs in the Rivers Po and Lambro in Northern Italy. Environ. Sci. Technol. 2003, 37, 1241-1248. [CrossRef]

17. Isidori, M.; Bellotta, M.; Cangiano, M.; Parrella, A. Estrogenic activity of pharmaceuticals in the aquatic environment. Environ. Int. 2009, 35, 826-829. [CrossRef] [PubMed]

18. Laurenson, J.P.; Bloom, R.A.; Page, S.; Sadrieh, N. Ethinyl Estradiol and Other Human Pharmaceutical Estrogens in the Aquatic Environment: A Review of Recent Risk Assessment Data. AAPS J. 2014, 16, 299-310. [CrossRef] 
19. Cocci, P.; Mozzicafreddo, M.; Angeletti, M.; Mosconi, G.; Palermo, F.A. In silico prediction and in vivo analysis of antiestrogenic potential of 2-isopropylthioxanthone (2-ITX) in juvenile goldfish (Carassius auratus). Ecotoxicol. Environ. Saf. 2016, 133, 202-210. [CrossRef]

20. Cocci, P.; Palermo, F.A.; Quassinti, L.; Bramucci, M.; Miano, A.; Mosconi, G. Determination of estrogenic activity in the river Chienti (Marche Region, Italy) by using in vivo and in vitro bioassays. J. Environ. Sci. 2016, 43, 48-53. [CrossRef]

21. Palermo, F.A.; Cocci, P.; Angeletti, M.; Polzonetti-Magni, A.; Mosconi, G. PCR-ELISA detection of estrogen receptor $\beta$ mRNA expression and plasma vitellogenin induction in juvenile sole (Solea solea) exposed to waterborne 4-nonylphenol. Chemosphere 2012, 86, 919-925. [CrossRef] [PubMed]

22. Palermo, F.A.; Mosconi, G.; Angeletti, M.; Polzonetti-Magni, A.M. Assessment of Water Pollution in the Tronto River (Italy) by Applying Useful Biomarkers in the Fish Model Carassius auratus. Arch. Environ. Contam. Toxicol. 2008, 55, 295-304. [CrossRef] [PubMed]

23. Cocci, P.; Capriotti, M.; Mosconi, G.; Palermo, F.A. Effects of endocrine disrupting chemicals on estrogen receptor alpha and heat shock protein 60 gene expression in primary cultures of loggerhead sea turtle (Caretta caretta) erythrocytes. Environ. Res. 2017, 158, 616-624. [CrossRef] [PubMed]

24. Blazer, V.S.; Walsh, H.L.; Shaw, C.H.; Iwanowicz, L.R.; Braham, R.P.; Mazik, P.M. Indicators of exposure to estrogenic compounds at Great Lakes Areas of Concern: Species and site comparisons. Environ. Monit. Assess. 2018, 190, 1-19. [CrossRef]

25. Cocci, P.; Palermo, F.A.; Pucciarelli, S.; Miano, A.; Cuccioloni, M.; Angeletti, M.; Roncarati, A.; Mosconi, G. Identification, partial characterization, and use of grey mullet (Mugil cephalus) vitellogenins for the development of ELISA and biosensor immunoassays. Int. Aquat. Res. 2019, 11, 389-399. [CrossRef]

26. Tollefsen, K.-E.; Bratsberg, E.; Bøyum, O.; Finne, E.F.; Gregersen, I.K.; Hegseth, M.; Sandberg, C.; Hylland, K. Use of fish in vitro hepatocyte assays to detect multi-endpoint toxicity in Slovenian river sediments. Mar. Environ. Res. 2006, 62, S356-S359. [CrossRef]

27. Tollefsen, K.-E.; Mathisen, R.; Stenersen, J. Induction of vitellogenin synthesis in an Atlantic salmon (Salmo salar) hepatocyte culture: A sensitivein vitrobioassay for the oestrogenic and anti-oestrogenic activity of chemicals. Biomarkers 2003, 8, 394-407. [CrossRef]

28. Cocci, P.; Capriotti, M.; Mosconi, G.; Campanelli, A.; Frapiccini, E.; Marini, M.; Caprioli, G.; Sagratini, G.; Aretusi, G.; Palermo, F.A. Alterations of gene expression indicating effects on estrogen signaling and lipid homeostasis in seabream hepatocytes exposed to extracts of seawater sampled from a coastal area of the central Adriatic Sea (Italy). Mar. Environ. Res. 2017, 123, 25-37. [CrossRef]

29. Pesonen, M.; Andersson, T.B. Fish primary hepatocyte culture; an important model for xenobiotic metabolism and toxicity studies. Aquat. Toxicol. 1997, 37, 253-267. [CrossRef]

30. Ellesat, K.S.; Yazdani, M.; Holth, T.F.; Hylland, K. Species-dependent sensitivity to contaminants: An approach using primary hepatocyte cultures with three marine fish species. Mar. Environ. Res. 2011, 72, 216-224. [CrossRef]

31. Zuccato, E.; Castiglioni, S.; Fanelli, R. Identification of the pharmaceuticals for human use contaminating the Italian aquatic environment. J. Hazard. Mater. 2005, 122, 205-209. [CrossRef]

32. Burcea, A.; Boeraş, I.; Mihuţ, C.-M.; Bănăduc, D.; Matei, C.; Curtean-Bănăduc, A. Adding the Mureş River Basin (Transylvania, Romania) to the List of Hotspots with High Contamination with Pharmaceuticals. Sustainability 2020, 12, 10197. [CrossRef]

33. Fick, J.; Söderström, H.; Lindberg, R.H.; Phan, C.; Tysklind, M.; Larsson, D.J. Contamination of Surface, Ground and Drinking Water from Pharmaceutical Production. Environ. Toxicol. Chem. 2009, 28, 2522-2527. [CrossRef]

34. Fliedner, A.; Rüdel, H.; Dreyer, A.; Pirntke, U.; Koschorreck, J. Chemicals of emerging concern in marine specimens of the German Environmental Specimen Bank. Environ. Sci. Eur. 2020, 32, 1-17. [CrossRef]

35. Zhang, X.; Lohmann, R.; Sunderland, E.M. Poly- and Perfluoroalkyl Substances in Seawater and Plankton from the Northwestern Atlantic Margin. Environ. Sci. Technol. 2019, 53, 12348-12356. [CrossRef] [PubMed]

36. Kolšek, K.; Mavri, J.; Dolenc, M.S.; Gobec, S.; Turk, S. Endocrine Disruptome-An Open Source Prediction Tool for Assessing Endocrine Disruption Potential through Nuclear Receptor Binding. J. Chem. Inf. Model. 2014, 54, 1254-1267. [CrossRef] [PubMed]

37. Cocci, P.; Mosconi, G.; Arukwe, A.; Mozzicafreddo, M.; Angeletti, M.; Aretusi, G.; Palermo, F.A. Effects of Diisodecyl Phthalate on PPAR: RXR-Dependent Gene Expression Pathways in Sea Bream Hepatocytes. Chem. Res. Toxicol. 2015, 28, 935-947. [CrossRef] [PubMed]

38. Palermo, F.A.; Cocci, P.; Mozzicafreddo, M.; Arukwe, A.; Angeletti, M.; Aretusi, G.; Mosconi, G. Tri-m-cresyl phosphate and PPAR/LXR interactions in seabream hepatocytes: Revealed by computational modeling (docking) and transcriptional regulation of signaling pathways. Toxicol. Res. 2015, 5, 471-481. [CrossRef]

39. Celiz, M.D.; Pérez, S.; Barceló, D.; Aga, D.S. Trace Analysis of Polar Pharmaceuticals in Wastewater by LC-MS-MS: Comparison of Membrane Bioreactor and Activated Sludge Systems. J. Chromatogr. Sci. 2009, 47, 19-25. [CrossRef]

40. Kim, J.-W.; Tue, N.M.; Isobe, T.; Misaki, K.; Takahashi, S.; Viet, P.H.; Tanabe, S. Contamination by perfluorinated compounds in water near waste recycling and disposal sites in Vietnam. Environ. Monit. Assess. 2012, 185, 2909-2919. [CrossRef]

41. Loos, R.; Wollgast, J.; Huber, T.; Hanke, G. Polar herbicides, pharmaceutical products, perfluorooctanesulfonate (PFOS), perfluorooctanoate (PFOA), and nonylphenol and its carboxylates and ethoxylates in surface and tap waters around Lake Maggiore in Northern Italy. Anal. Bioanal. Chem. 2007, 387, 1469-1478. [CrossRef] 
42. Smeets, J.M.; Rankouhi, T.R.; Nichols, K.M.; Komen, H.; Kaminski, N.E.; Giesy, J.P.; van den Berg, M. In VitroVitellogenin Production by Carp (Cyprinus carpio) Hepatocytes as a Screening Method for Determining (Anti)Estrogenic Activity of Xenobiotics. Toxicol. Appl. Pharmacol. 1999, 157, 68-76. [CrossRef]

43. Cocci, P.; Mosconi, G.; Palermo, F.A. Changes in expression of microRNA potentially targeting key regulators of lipid metabolism in primary gilthead sea bream hepatocytes exposed to phthalates or flame retardants. Aquat. Toxicol. 2019, 209, 81-90. [CrossRef]

44. Cocci, P.; Mosconi, G.; Palermo, F.A. Pregnane X receptor (PXR) signaling in seabream primary hepatocytes exposed to extracts of seawater samples collected from polycyclic aromatic hydrocarbons (PAHs)-contaminated coastal areas. Mar. Environ. Res. 2017, 130, 181-186. [CrossRef] [PubMed]

45. Ribecco, C.; Baker, M.E.; Šášik, R.; Zuo, Y.; Hardiman, G.; Carnevali, O. Biological effects of marine contaminated sediments on Sparus aurata juveniles. Aquat. Toxicol. 2011, 104, 308-316. [CrossRef]

46. Vieira, F.A.; Pinto, P.I.; Guerreiro, P.M.; Power, D.M. Divergent responsiveness of the dentary and vertebral bone to a selective estrogen-receptor modulator (SERM) in the teleost Sparus auratus. Gen. Comp. Endocrinol. 2012, 179, 421-427. [CrossRef]

47. Cabas, I.; Liarte, S.; García-Alcázar, A.; Meseguer, J.; Mulero, V.; García-Ayala, A. $17 \alpha$-Ethynylestradiol alters the immune response of the teleost gilthead seabream (Sparus aurata L.) both in vivo and in vitro. Dev. Comp. Immunol. 2012, 36, 547-556. [CrossRef] [PubMed]

48. Pérez-Sánchez, J.; Borrel, M.; Bermejo-Nogales, A.; Benedito-Palos, L.; Saera-Vila, A.; Calduch-Giner, J.A.; Kaushik, S. Dietary oils mediate cortisol kinetics and the hepatic mRNA expression profile of stress-responsive genes in gilthead sea bream (Sparus aurata) exposed to crowding stress. Implications on energy homeostasis and stress susceptibility. Comp. Biochem. Physiol. Part D Genom. Proteom. 2013, 8, 123-130. [CrossRef] [PubMed]

49. Navas, J.M.; Segner, H. Vitellogenin synthesis in primary cultures of fish liver cells as endpoint for in vitro screening of the (anti)estrogenic activity of chemical substances. Aquat. Toxicol. 2006, 80, 1-22. [CrossRef] [PubMed]

50. Gallagher, P.E.; Li, P.; Lenhart, J.R.; Chappell, M.C.; Brosnihan, K.B. Estrogen Regulation of Angiotensin-Converting Enzyme mRNA. Hypertension 1999, 33, 323-328. [CrossRef]

51. Zilberman, J.M.; Licy, Y.L.; Sartori-Vallinoti, J.C.; Iliescu, R.; Reckelhoff, J.F. Angiotensin converting enzyme inhibitor upreg-ulates the expression of estrogen receptors in the kidney in old female rats. Faseb J. 2008, 22, 941-948. [CrossRef]

52. Lau, C.; Anitole, K.; Hodes, C.; Lai, D.; Pfahles-Hutchens, A.; Seed, J. Perfluoroalkyl Acids: A Review of Monitoring and Toxicological Findings. Toxicol. Sci. 2007, 99, 366-394. [CrossRef]

53. DRBC. Contaminants of Emerging Concern in the Delaware River Basin. 2016. Available online: http://www.nj.gov/drbc/ quality/reports/emerging/ (accessed on 16 April 2021).

54. Lindstrom, A.B.; Strynar, M.J.; Libelo, E.L. Polyfluorinated Compounds: Past, Present, and Future. Environ. Sci. Technol. 2011, 45, 7954-7961. [CrossRef] [PubMed]

55. Singh, S.; Singh, S.K. Effect of gestational exposure to perfluorononanoic acid on neonatal mice testes. J. Appl. Toxicol. 2019, 39, 1663-1671. [CrossRef] [PubMed]

56. Benninghoff, A.D.; Bisson, W.H.; Koch, D.C.; Ehresman, D.J.; Kolluri, S.K.; Williams, D.E. Estrogen-Like Activity of Perfluoroalkyl Acids In Vivo and Interaction with Human and Rainbow Trout Estrogen Receptors In Vitro. Toxicol. Sci. 2010, 120, 42-58. [CrossRef] [PubMed]

57. Jantzen, C.E.; Annunziato, K.A.; Bugel, S.M.; Cooper, K.R. PFOS, PFNA, and PFOA sub-lethal exposure to embryonic zebrafish have different toxicity profiles in terms of morphometrics, behavior and gene expression. Aquat. Toxicol. 2016, 175, 160-170. [CrossRef] [PubMed]

58. Jurima-Romet, M.; Huang, H.S.; Paul, C.J.; Thomas, B.H. Enalapril cytotoxicity in primary cultures of rat hepatocytes. II. Role of glutathione. Toxicol. Lett. 1991, 58, 269-277. [CrossRef]

59. Purclutepe, O.; Iskender, G.; Kiper, H.D.; Tezcanli, B.; Selvi, N.; Avci, C.B.; Kosova, B.; Gokbulut, A.A.; Sahin, F.; Baran, Y.; et al. Enalapril-induced apoptosis of acute promyelocytic leukaemia cells involves STAT5A. Anticancer. Res. 2012, 32, $2885-2893$. [PubMed]

60. Louisse, J.; Rijkers, D.; Stoopen, G.; Janssen, A.; Staats, M.; Hoogenboom, R.; Kersten, S.; Peijnenburg, A. Perfluorooctanoic acid (PFOA), perfluorooctane sulfonic acid (PFOS), and perfluorononanoic acid (PFNA) increase triglyceride levels and decrease cholesterogenic gene expression in human HepaRG liver cells. Arch. Toxicol. 2020, 94, 3137-3155. [CrossRef]

61. Aerni, H.-R.; Kobler, B.; Rutishauser, B.V.; Wettstein, F.E.; Fischer, R.; Giger, W.; Hungerbühler, A.; Marazuela, M.D.; Peter, A.; Schönenberger, R.; et al. Combined biological and chemical assessment of estrogenic activities in wastewater treatment plant effluents. Anal. Bioanal. Chem. 2003, 378, 688-696. [CrossRef]

62. Lozano, N.; Rice, C.P.; Pagano, J.; Zintek, L.; Barber, L.B.; Murphy, E.W.; Nettesheim, T.; Minarik, T.; Schoenfuss, H.L. Concentration of organic contaminants in fish and their biological effects in a wastewater-dominated urban stream. Sci. Total. Environ. 2012, 420, 191-201. [CrossRef]

63. Madsen, L.L.; Korsgaard, B.; Pedersen, K.L.; Bjerregaard, L.B.; Aagaard, T.; Bjerregaard, P. Vitellogenin as biomarker for estrogenicity in flounder Platichthys flesus in the field and exposed to $17 \alpha$-ethinylestradiol via food and water in the laboratory. Mar. Environ. Res. 2013, 92, 79-86. [CrossRef] [PubMed]

64. Ankley, G.T.; Jensen, K.M.; Kahl, M.D.; Korte, J.J.; Makynen, E.A. Description and evaluation of a short-term reproduction test with the fathead minnow (Pimephales promelas). Environ. Toxicol. Chem. 2001, 20, 1276-1290. [CrossRef] [PubMed] 
65. Hinck, J.E.; Blazer, V.S.; Denslow, N.D.; Echols, K.R.; Gross, T.S.; May, T.W.; Anderson, P.J.; Coyle, J.J.; Tillitt, D.E. Chemical contaminants, health indicators, and reproductive biomarker responses in fish from the Colorado River and its tributaries. Sci. Total. Environ. 2007, 378, 376-402. [CrossRef]

66. Pomatto, V.; Palermo, F.; Mosconi, G.; Cottone, E.; Cocci, P.; Nabissi, M.; Borgio, L.; Polzonetti-Magni, A.M.; Franzoni, M.F Xenoestrogens elicit a modulation of endocannabinoid system and estrogen receptors in $4 \mathrm{NP}$ treated goldfish, Carassius auratus. Gen. Comp. Endocrinol. 2011, 174, 30-35. [CrossRef] [PubMed]

67. Larsen, B.K.; Bjørnstad, A.; Sundt, R.C.; Taban, I.C.; Pampanin, D.M.; Andersen, O.K. Comparison of protein expression in plasma from nonylphenol and bisphenol A-exposed Atlantic cod (Gadus morhua) and turbot (Scophthalmus maximus) by use of SELDI-TOF. Aquat. Toxicol. 2006, 78, S25-S33. [CrossRef]

68. Petersen, K.; Tollefsen, K.E. Assessing combined toxicity of estrogen receptor agonists in a primary culture of rainbow trout (Oncorhynchus mykiss) hepatocytes. Aquat. Toxicol. 2011, 101, 186-195. [CrossRef]

69. Griffin, L.B.; January, K.E.; Ho, K.W.; Cotter, K.A.; Callard, G.V. Morpholino-Mediated Knockdown of ER $\alpha$, ER $\beta a$, and ER $\beta b$ mRNAs in Zebrafish (Danio rerio) Embryos Reveals Differential Regulation of Estrogen-Inducible Genes. Endocrinology 2013, 154, 4158-4169. [CrossRef] [PubMed]

70. Nelson, E.R.; Habibi, H.R. Functional Significance of Nuclear Estrogen Receptor Subtypes in the Liver of Goldfish. Endocrinology 2010, 151, 1668-1676. [CrossRef]

71. Murakami, M.; Imamura, E.; Shinohara, H.; Kiri, K.; Muramatsu, Y.; Harada, A.; Takada, H. Occurrence and Sources of Perfluorinated Surfactants in Rivers in Japan. Environ. Sci. Technol. 2008, 42, 6566-6572. [CrossRef] 